\title{
Guidelines for the integration of EMS based in ISO 14001 with Cleaner Production
}

\author{
José Augusto de Oliveira ${ }^{a *}$, Otávio José de Oliveira ${ }^{\mathrm{b}}$, \\ Aldo Roberto Ometto ${ }^{\mathrm{a}}$, Helena Freitas Capparelli ${ }^{\mathrm{a}}$ \\ a*Universidade de São Paulo, São Carlos, SP, Brasil, joseaugusto@sc.usp.br \\ bUniversidade Estadual Paulista, Guaratinguetá, SP, Brasil
}

\begin{abstract}
This study aims to propose guidelines for the integration of the Environmental Management System (EMS) based on ISO 14001 with the Cleaner Production (CP). For this, a systematic review was applied and five case studies have been carried out in industrial companies with considerable environmental performance. Located in the state of São Paulo, the researched companies have got CP projects to ensure environmental and economic gains and shown prominent compatibilities with the EMS based on ISO 14001. The proposed guidelines were performed in three parts: the planning stage, the integration stage and the stage of evaluation and analysis. The main compatibilities include dissemination of the environmental culture, synergy between some specific requirements of the standard and the CP, as the general requirements, legal requirements, environmental policy, training, qualification and monitoring. The guidelines can increase operational efficiency and strategic environmental management in enterprises.
\end{abstract}

\section{Keywords}

Environmental Management System. ISO 14001. Cleaner Production. Integration. Brazilian industries.

\section{Introduction}

The Adoption of environmental practices is not only an answer to increasingly strict environmental policies, but also a source of competitive advantage, as in the case of companies that export their products to markets where environmental concerns are high; to improve their image and reputation (Cagno et al., 2005; Rao \& Holt, 2005; Frondel et al., 2007). In order to provide sustainable business, several models of environmental management were created, as part of the effort to instrumentalize concepts and objectives for sustainable development, such as: Eco efficiency by the World Business Council for Sustainable Development (WBCSD) and Organization for Economic Co-operation and Development (OCDE); the Natural Step created by the Prof. Karl-Henrik Robèrt; Cleaner Production (CP) developed by United Nations Environment Programme (UNEP) and United Nations Industrial Development Organization (UNID0) and ISO 14001, among others (Frondel et al., 2007; United Nations Environment Programme, 2002; United Nations Industrial Development Organization, 2011).
Brazil is going through strong economic growth. In 2010, Gross Domestic Product (GDP) was US\$ 1,571,957 million (Instituto Brasileiro de Geografia e Estatística, 2010). A total of 308 business units received ISO 14001 certification in 2011 in the country (Instituto Nacional de Metrologia, Qualidade e Tecnologia, 2011). Although its environmental legislation is still focused on treatment practices, the search for proactive and preventive initiatives can be observed in Brazil to attend the global market demand. With great natural wealth and the industrial and economic growth the country is going through, Brazil deserves to be highlighted for the adoption of environmental initiatives and measures that promote equilibrium between economic growth and environmental responsibility.

$\mathrm{CP}$ is a continuous strategy for promoting productive eco-efficiency by minimizing the use of inputs and waste generation (Cagno et al., 2005; United Nations Environment Programme, 2002; United Nations Industrial Development Organization, 2011); Shi et al., 2010). It is an effective mechanism 
for industries to improve their production processes and means of controlling their environmental aspects and impacts.

This strategy was created in the 90s by the UNEP (United Nations Environment Programme, 2002; United Nations Industrial Development Organization, 2011) and has been very well accepted by the companies due yours potential in raising environmental and economic benefits (Kleměs et al., 2012; Thoumy \& Vachon, 2012; Silva et al., 2013; Riaz et al., 2013; Van Hoof \& Lyon, 2013; Yusup et al., 2014).

The $\mathrm{CP}$ uses techniques that prevent environmental degradation in the exploration of natural resources, with a focus on minimizing input use, as well as in the reduction of pollution caused by waste generation through practices that permit minimizing resource uses and emission generation, and then with reuse and recycling practices (Fresner, 1998; Gale, 2005; United Nations Environment Programme, 2002; Shi et al., 2010; Silva et al., 2013; Yusup et al., 2014).

The Environmental Management System (EMS) was created with the objective of planning and organizing administrative and operational activities to obtain greater efficiency in actions taken, reduce repetitions, redundancy and conflicts among the different agents in charge of actions, from the strategic to the operational levels.

An EMS based on ISO 14001 proposes the development and implementation of its environmental policy to manage its environmental aspects, which are the elements of the organization's activities, products or services that can interact with the environment (Eisenhartd, 1998; Lee \& Koh, 2002; Gale, 2005; Frondel et al., 2007; International Organization for Standardization, 2004; Campos, 2012; Khalili \& Duecker, 2013). This EMS is one of the most widely adopted by the companies. (Campos, 2012; Khalili \& Duecker, 2013).

They are two different elements of environmental management under various aspects (Fresner, 1998; Silva \& Medeiros, 2004; Khan, 2006; Frondel et al., 2007) and they reveal distinct advantages, difficulties and specificities between each other, generating several discussions in the academic and business realms about their particularities in relation to environmental performances promoted at the companies (Frondel et al., 2007). However, in some important points there are convergences that require studies aimed at integrating these elements, thus permitting their simultaneous application with the objective of increasing the company's Ecoefficiency (Zeng et al., 2005; Khan, 2006).

The systematization of environmental tools and the integration of CP and EMS based on ISO 14001 allows an improvement in the management and prevention of environmental impacts of production, reducing the costs of treating these as well as maximizing performance and eco-efficiency in plants (Fryxell \& Szeto, 2002; Fresner, 1998; Gale, 2005; Khan, 2006; Frondel et al., 2007). Therefore, organizations will use preventive environmental management tools, supported by CP and corrective sustained by this EMS (Fresner, 1998; United Nations Environment Programme, 2002; Frondel et al., 2007; Rao \& Holt, 2005; Gale, 2005; Khan, 2006; Shi et al., 2010; United Nations Industrial Development Organization, 2011). Moreover, the proper implantation of a CP program may meet many of the auditable requirements of ISO 14001, for example, in aspects of improvement and environmental impact monitoring (Khan, 2006; Kleměs et al., 2012). In contrast, researchers say that the proper conduct of an EMS based on 1SO 14001:2004 automatically promotes improvements in the $\mathrm{CP}$ programs in companies (Zeng et al., 2005).

In this context, the questions guiding this research were: are there compatibilities between the EMS based on ISO 14001 and the CP? These compatibilities can contribute to the integration of both?

With the proposal of including a proactive and preventive strategy, geared towards improving processes and products at industries, this paper aims to propose guidelines for the integration of the EMS based on ISO 14001 and Cleaner Production.

\section{Methodology}

An exploratory literature review was conducted to support a Systematic Review (SR) and the field research, a multiple case study.

To obtain greater reliability in the research process and search for scientific papers which address a specific combination of different themes, applies a systematic method for a specific data collection that can be replicated in each stage of the researching process (Tranfield et al., 2003; Stechemesser \& Guenther, 2012). This method shows the comparison based on specific parameters, showing contrasts and differences elucidating different aspects of the issue (Biolchini et al., 2005, 2007).

The SR identified the main compatibilities between EMS ISO 14001 and CP and contributed to discuss the topics with the case studies. This research method was conducted in late 2011 and found a sample of 480 publications about the topics: EMS, ISO 14001 and CP.

Key words were combined and used in 5 different research data basis (Science Direct, Scirus, Scielo, IEEE Explores, Compendex) to search articles and 
publications during the period of 2002 and 2010 . The following key words were used:

- Procedures and Environmental Management System;

- Methods and Environmental Management System;

- Tools and Environmental Management System;

- Procedures and Cleaner Production;

- Methods and Cleaner Production;

- Tools and Cleaner Production;

- Environmental Management and Cleaner Production.

The key words were chosen by the questions raised before while trying to understand how the EMS ISO 14001 and CP could be combined or interact together.

For the evaluation of the articles and publications, a pre-selection was performed by analysis of the summary. After verifying if the subject was in accordance with the research they were separated in three categories to define if they presented: procedures, methods or tools from environmental management system and/or cleaner production.

The studies were registered in a table containing:

- Title of the study

- Author(s)

- Keywords mentioned in the study

- Source

- Publish year.

After the first register the study was then classified by its procedure, method or tools considering:

- Nature (prescriptive, analytical or comparative);

- Type (Checklist, guide, matrix or software);

- Level of maturity (Theoretical, experimental or consolidated);

- Method for environmental impact assessment (yes or no);

- Level of detail (superficial, succinct or complete).

After this second classification the procedures, methods or tools were analyzed to check in which step of either EMS ISO 14001 or CP they were associated. A matrix containing all the steps for both (EMS ISO 14001 and CP) was created crossing all the procedures, methods and tools found in all 480 studies. When analyzing the studies more carefully, it was found that most tackles independently and not integrated.

Furthermore, the qualitative investigation of phenomena and exploration of information applied by the method of case studies was based on different instruments of data collection enabling the triangulation of data and thus greater reliability to results ensuring adequate contribution to the theory (Yin, 2003; Jupp, 2006).

According Cauchick-Miguel (2007), the method of case study becomes relevant when studied at least four cases, because it does not restrict the search to a specific reality of a few companies. Moreover, adopting many cases can endanger the depth of obtaining and analyzing the information (Voss et al., 2002). Thus, we chose to search five case studies, following Voss et al. (2002) and Cauchick-Miguel (2007) recommendations.

Visits, document analyses, semi-structured interviews, and analysis of processes and industrial facilities were conducted. In order to increase the reliability of the results, a case cross examination was conducted that refined compatibilities between the EMS ISO 14001 and CP and enabled the creation of guidelines targeted to integration.

In order to be part of the research sample, organizations had to meet the following criteria:

- To have efficient EMS based on ISO 14001 and be considered success stories in $\mathrm{CP}$ according to the Environmental Company of São Paulo State (CETESB);

- To have the potential to contribute towards the study in relation to its practices as well as its availability for conducting case studies; and

- To be a company located in the state of São Paulo. Initial contact with the companies was made by phone, thus explaining the objectives to the companies' environmental managers, called Management Representatives (MR), production managers and other employees with knowledge on the topics. In the next phase, data were collected after analysis of EMS based ISO 14001 documents and the CP structure presented (Jupp, 2006). The industries production processes and their main $\mathrm{CP}$ projects were also analyzed onsite.

This was performed according to a visit schedule conducted at all the companies, along with their environmental and process managers and employees (Yin, 2003). Table 1 illustrates the macro structure for the semi-structured interview script applied to the employees of those studied organizations.

Each phase of the interview script was comprised of questions elaborated from the literature review conducted in the study. The questions encompassed the main elements about those themes studied in the paper. These questions were made directly to the MRs and their assistants. Some answers were redone when necessary, such as in cases of information provided by the manager that was divergently verified in documents or production processes. 
Thus, several contacts were promoted in a continuous manner after the interviews, making it possible to refine the information gathered and to maximize the veracity of data provided in the study (Shah \& Corley, 2006).

\section{Case studies}

The five enterprises studied include three multinationals and two Brazilian companies. They are certified according to ISO 14001 and are considered success stores in CP by the CETESB. Companies 1 and 3 are chemical industries, 2 and 4 are from the pulp sector and the organization 5 operates in the automotive sector. The case studies were carried out in the end of 2012. Table 2 illustrates the general characterization of each company studied.

Table 2 shows that all five companies are large. They all participate actively in the international market through exportation and already had a generic EMS in operation before to obtaining ISO 14001 certification. With the exception of company 4, they all have ISO 9001 certification, obtained prior to ISO 14001 certification. The fact they had ISO 9001 certification, and mainly had a generic EMS in operation, significantly facilitated the ISO 14001 certification process.

The main benefits earned by EMS organizations were: minimization of environmental impacts; improvement in pollution control and management; improvement in organizational culture concerning the environment; reduction in raw material use; and improvements in company image with improved communication of the company with society.

Table 1. Macro structure of the interview script.

\begin{tabular}{cl}
\hline Phase & \multicolumn{1}{c}{ Interview focus } \\
\hline 1 & General characterization of the company \\
2 & Characterization of the EMS \\
3 & Characterization of the CP procedures \\
4 & Phases and steps for implementing CP \\
5 & CP compatibilities for EMS \\
6 & EMS compatibilities for CP \\
\hline
\end{tabular}

All of the companies had an Integrated Management System (IMS) that unified the Quality Management System (QMS) to the EMS based on ISO 14001, including the EMS Policy as well as goals, values, manuals and objectives.

The MRs at companies 1, 2 and 5 stated they had difficulties in adapting the organizational culture and procedures to norm requirements, which generated resistance among employees. But, with time, this difficulty was overcome. Managers of organizations 4 and 5 confirmed difficulties such as internal resistance by employees and excessive bureaucracy (documents) of the norm.

These difficulties are interconnected since they represent the adjustment of the companies' EMS to specific requirements of the norm. These difficulties were seen in all the companies because they all had an EMS previously installed, before ISO 14001 certification, thus only minor adaptations of a document nature were needed to meet the norm's requirements.

With the exception of company 2, the others are not official members of the CP program created by UNEP. Their environmental programs do not use this nomenclature and they do not follow the methodology proposed by UNEP exactly. However, those programs are used by the organizations for achieve economic and environmental benefits with a focus on pollution prevention, reducing the use of natural resources and minimizing environmental impacts, characterizing $\mathrm{CP}$ practices.

Table 3 shows the results observed in the companies and in interviews with Environmental Managers. It shows the convergences between the EMS and CP. No significant friction was observed at any of the companies according to those interviewed, that is, one did not jeopardize the other. This result was expected since the management system, in this case the EMS, should serve the CP strategy, so much so that the requirements of this norm apply to any company and any management model, as mentioned before.

Table 3 presents the main compatibilities observed in the studied companies, among the requirements of ISO 14001 and the CP (environmental policy; environmental aspects; legal requirements;

Table 2. General characterization of studied companies.

\begin{tabular}{lccccc}
\hline \multicolumn{1}{c}{ Companies } & 1 & 2 & 3 & 4 & 5 \\
\hline Revenues (millions of Dollars in 2011) & 2.63 & 4.24 & 12.36 & - & 2.41 \\
No. of Collaborators & 3486 & 14600 & 3444 & 450 & 12500 \\
Consulting in implementation of ISO 14001 & No & No & No & Yes & Yes \\
Had an EMS before ISO 14001? & Yes & Yes & Yes & Yes & Yes \\
Year of last ISO 9001 certification & 2009 & 2000 & 2009 & - & 2004 \\
Year of last ISO 14001 certification & 2009 & 2004 & 2009 & 2009 & 2004 \\
\hline
\end{tabular}


Table 3. Compatibilities between ISO 14001 requirements and $\mathrm{CP}$ at companies.

\begin{tabular}{|l|c|c|c|c|c|}
\hline & \multicolumn{5}{|c|}{ Companies } \\
\hline \multicolumn{1}{|c|}{ IS0 14001 requirements } & 1 & 2 & 3 & 4 & 5 \\
\hline General Requirements & $\checkmark$ & $\checkmark$ & $\checkmark$ & & \\
\hline Environmental Policy & $\checkmark$ & $\checkmark$ & & $\checkmark$ & $\checkmark$ \\
\hline Environmental aspects & $\checkmark$ & $\checkmark$ & $\checkmark$ & $\checkmark$ & $\checkmark$ \\
\hline Legal requirements and others & & $\checkmark$ & $\checkmark$ & $\checkmark$ & $\checkmark$ \\
\hline Objectives, goals and programs & $\checkmark$ & $\checkmark$ & & $\checkmark$ & $\checkmark$ \\
\hline $\begin{array}{l}\text { Resources, functions, } \\
\text { responsibility and authorities }\end{array}$ & $\checkmark$ & $\checkmark$ & & & \\
\hline $\begin{array}{l}\text { Competence, training and } \\
\text { awareness }\end{array}$ & $\checkmark$ & & $\checkmark$ & & $\checkmark$ \\
\hline Communication & & & & & $\checkmark$ \\
\hline Documentation & & & & & \\
\hline Document control & & & & & \\
\hline Operational control & $\checkmark$ & $\checkmark$ & & & $\checkmark$ \\
\hline $\begin{array}{l}\text { Preparation and response to } \\
\text { emergencies }\end{array}$ & & & & & \\
\hline Monitoring and measurement & $\checkmark$ & $\checkmark$ & $\checkmark$ & $\checkmark$ & \\
\hline $\begin{array}{l}\text { Assessment of meeting legal } \\
\text { requirements and others }\end{array}$ & & $\checkmark$ & & & $\checkmark$ \\
\hline $\begin{array}{l}\text { Non-conformities, corrective } \\
\text { action and preventive action }\end{array}$ & & $\checkmark$ & & & \\
\hline Control of records & $\checkmark$ & & $\checkmark$ & & \\
\hline Internal Audit & & $\checkmark$ & & & \\
\hline $\begin{array}{l}\text { Critical analysis by top } \\
\text { management }\end{array}$ & & & & $\checkmark$ & \\
\hline
\end{tabular}

objectives, goals and programs; and monitoring and measurement). According to the interviews, one factor underscored by the company managers was the concern to implement new projects where environmental impacts were already focused and measured in the project phase, in consonance with the ISO 14001 and CP programs, such as: pollution prevention, recycling and management and disposal of inputs generated in the companies' different production sectors.

$\mathrm{CP}$ also has a policy geared towards meeting legal guidelines, such as the reduction in environmental impacts, thus complying with norm requirements. This also occurs for nonconformity requirements, with corrective and preventive actions, not as a tool, but rather as a correction in process failures and which are considered nonconformities and internal audits, as a demonstration of continuous improvement.

Also in relation to Table 3, companies do not converge in only four items, that is: Documentation; Control of documents, Nonconformity, corrective and preventive action, and critical analysis by top management.

\section{Discussion}

In every case, there are departments led by environment or integrated management system managers who report directly to each company's industrial director. Furthermore, the five organizations are large in terms of revenues as well as in numbers of employees. They are all certified in ISO 14001 and adopt $\mathrm{CP}$ procedures, thus, the crossing of cases became appropriate since it was done among companies with similar characteristics, which recall the objective of this study.

Although all of the companies have ISO 14001 certification, their MRs attributed the motivation to obtain certification to adjustments to the market, because they had efficient EMS in operation that are even more encompassing than what is proposed by ISO 14001 . Thus, the difficulties faced by the organizations, observed in the study for ISO 14001 certification, were to adjust to the needed documentation and to the work standardization routine required by the norm.

The requirement "Environmental Policy" of ISO 14001 was seen in 4 of the 5 case studies as strong support for the implementation of CP in companies. The $\mathrm{CP}$ also has a policy aimed at meeting the legislation and environmental improvements in the companies, however this compatibility has not been verified in literature. This finding implies that we cannot yet verify the theory or support a correlation between this requirement of the standard with the $\mathrm{CP}$, but it was observed that in practice and in business such thing occurs in Brazilian industry. The Environmental Policy of the EMS is disseminated throughout the company and assists the implementation of projects of $\mathrm{CP}$, it stimulates the company to focus action on environmental improvements.

It can be considered that the Environmental Policy can be used by another environmental program adopted by the company, especially by $\mathrm{CP}$, since it indicates the position of the company, with goals and objectives of the organization in relation to environmental issues. Thus, it is worth noting that the company's Environmental Policy can be introduced in an integrated manner for both the EMS and the $\mathrm{CP}$. The environmental policy of a company should reflect the organization's stance in relation to the environment and could, in this case, provide all the tools, systems and environmental management models that the company adopts to reduce their environmental impacts and improve environmental performance.

The requirement "Environmental Aspects" was identified as compatible with the $\mathrm{CP}$ in the five case studies and was also nominated in the SR, which shows its strong relationship to aid the implementation of CP. 
In the literature, it was observed that the requirement of the standard can contribute to the assessment phase, identifying and selecting opportunities, mass balance and design flowchart for the implementation of CP in companies (Fresner, 1998; Lee \& Koh, 2002; Gale, 2005; Giannetti et al., 2008; Suh, 2004; Khan et al., 2002; Darbra et al., 2004; Ganeshkumar et al., 2009; Burke \& Gaughran, 2006; Tove \& Mauritz, 2006). This requirement of the standard can still subsidize the deployment of CP options (Darbra et al., 2004; Ganeshkumar et al., 2009; Burke \& Gaughram, 2006; Tove \& Mauritz, 2006; Tam et al., 2006a).

It is observed that the requirement "Environmental Aspects" of ISO 14001 provides high compatibility with $\mathrm{CP}$ and can serve as an aid to the implementation of projects of this strategy in a systematic manner and jointly as the same tools for identifying, assessing and managing environmental aspects used for EMS ISO 14001 can be used for the CP, decreasing costs, efforts and barriers, in addition to increase the efficiency and effectiveness of the use of tools.

The item "Legal Requirements" of ISO 14001 was identified as a facilitator for the implementation of the $\mathrm{CP}$ in four companies, because this environmental strategy also provides compliance with current environmental legislation. However, this compatibility was not identified in the SR, but it may be noted that in practice this cooperative relationship exists and the companies that cater to the requirement of the standard benefit in the implementation of projects of $\mathrm{CP}$, or unlike, anticipating to comply with environmental legal requirements.

The requirement of the standard "Objectives, targets and programs" contributed to the implementation of the CP in 4 enterprises and aiding this relationship was also confirmed by the SR. This requirement of the standard guides the setting of priorities, goals and objectives of the CP (Matthews et al., 2004; Cerávolo \& Müller, 2006). According to the literature, the requirement of ISO 14001 benefits the technical evaluation, environmental and economic of CP. So it is clear the compatibility requirement of the standard with the $\mathrm{CP}$, since the with requirement to meet the standard, the company evaluates the environmental feasibility, and economic and technical aspects of the implementation of projects of $\mathrm{CP}$ at the purpose of environmental improvements in the production process (Barbiroli \& Raggi, 2003).

The requirement "Monitoring and Measurement" of ISO 14001 was deemed compatible with the CP in four companies and also by the results of the SR. This requirement of the standard contributes to the mass balance, the definition of performance indicators, identification of causes, identification of barriers, identification of CP options in companies (Gale, 2005; Lee \& Koh, 2002; Gianetti et al., 2008; Scavone, 2006; Burritt et al., 2009; Staniskis \& Stasiskiene, 2006; Nagel, 2003; Lundberg et al., 2009; Jasch, 2003) and the evaluation of environmental sustainability, economic and technical CP options. Because it can measure the positive and negative points of the implemented projects and the CP plan continuous improvement (Gale, 2005; Tam et al., 2006a, b; Matthews et al., 2004; Cerávolo \& Müller, 2006; Scavone, 2006; Staniskis \& Stasiskiene, 2006; Nagel, 2003; Jasch, 2003; Jaju \& Mohanty, 2008).

Compliance with the requirements "Documentation" and "Control of documents" for companies didn't help the CP. It was found also the lack of compatibility by literature review. However, the exploration of opportunities CP contributes with the control and management of environmental aspects, and so help significantly in the records and documentation required by ISO 14001 (Khan, 2006; Khan et al., 2002). It was stood out this requirement in particular, because it showed no convergence in the analysis of case studies. But it is worth mentioning that the control of documents to the EMS and the CP could be held jointly, thus minimizing operational wear, since in general practices and environmental projects adopted by the $\mathrm{CP}$, contributing to the care of most of the requirements of ISO 14001, performed audits required by the EMS.

\section{Guidelines for mutual support between the requirements of 1SO 14001 and Cleaner Production}

EMS in Brazil often focuses on compliance with legal requirements, on meeting the needs of stakeholders for competitive advantage and improving the company's image, not thereby prioritizing the potential that this management system has to contribute on environmental improvements in the company. Thus, the integration of the standard requirements that drive the deployment and maintenance of EMS with the CP can contribute to maximize the efficiency of the organization's environmental performance, while minimizing operating costs, optimize human, financial and structural resources.

These guidelines can be used by companies of all sizes, as well as in the same way as the EMS ISO 14001 and CP. However, one can consider some peculiarities such as financial strength, technological and human resources, potential differences as to this integration, in other words, for companies studied in this research, this integration tends to be facilitated. 
The guidelines also avoid defining an excessive number of steps and tools, to increase their application at companies from different businesses and different sizes.

In order to structure the proposed guidelines for integration, a separation was made in three stages: the planning stage, the integration stage and the stage of evaluation and analysis, as shown in Figure 1.

\subsection{Planning of integration stage}

\subsubsection{Definition of staff, training and capacity}

The definition of a team is a key to the success of the EMS, which is usually led by an MR, which is directly subordinated to the senior management for the treatment of issues related to management system certification and ISO 14001. Known as Ecotime, the team set to the $\mathrm{CP}$ should propose, implement and manage $\mathrm{CP}$ projects in companies.

This team should be integrated or be formed by the same people in both the EMS and in the CP. This integration contributes positively to the development and training, employee awareness, communication, and reduces the workload and operational risks, making environmental management practices in business more efficient and reducing costs.

At this time, the EMS staff must have technical training environment, it takes a more practical environmental performance of the company. The tools used for the EMS can contribute to the process of decision made for the CP and for all the company's environmental management. Although the CP does not necessarily require a document entitled Environmental Policy, the existence of this document towards the environment causes environmental awareness is promoted in all sectors of the organization, thus stimulating the search for environmental improvements and the proposed CP projects.

This awareness promoted throughout the company to comply with its environmental objectives must be based on training and capacity, in which the objectives and targets are accessible to all levels of the company.

The use of Brainstorming regularly is a important way to identify necessities of the team. In the integration context, the team should be encouraged to identify environmental improvements in their daily activities.

\subsubsection{Formulation of goals and objectives}

Both the EMS as CP have focused on minimizing the environmental impacts of businesses, whether caused by natural resource extraction, the waste and effluent production and disposal of these products or by. Thus, the objectives and goals of the EMS integrated with the practices of pollution prevention, recycling, and within the production and reuse of production inputs proposed by the $\mathrm{CP}$, complement the environmental objectives of the companies.

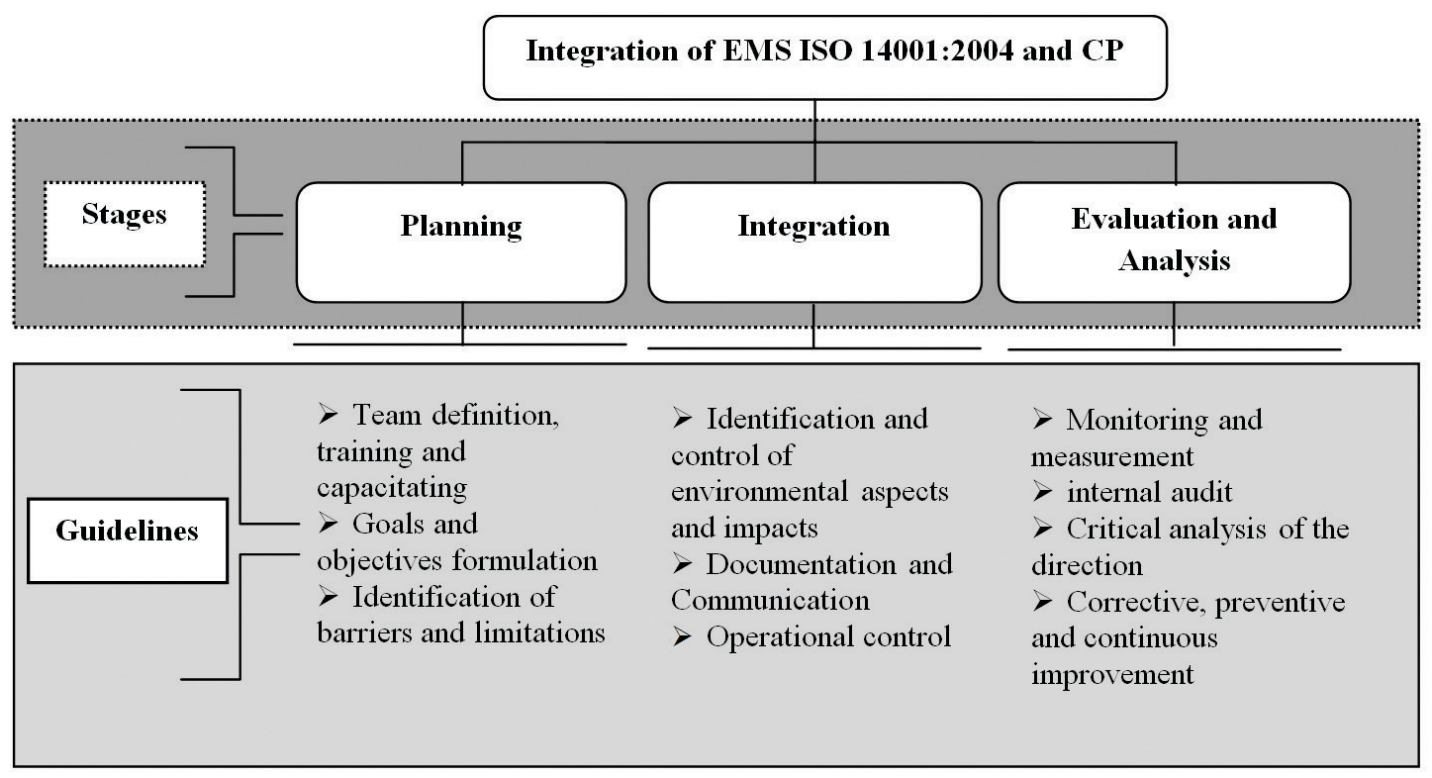

Figure 1. Propose for integration of EMS ISO 14001 and CP. 
The management techniques used in EMS are well subsidized and supported by technical elements of production, making the EMS with preventive and minimizing the need for treatment, despite numerous criticisms made of the EMS for its remedial nature, the which means more costs for the company.

Thus, the objectives of the EMS and CP must be aligned. Often they may be the same as minimizing the environmental impact of certain or may be complementary in the sense of operations.

Under an integrated approach to EMS and CP, a company must establish its strategic, tactical and operational objectives with environmental targets included.

With training and knowledge of the environmental goals of the organization, each employee can contribute to the identification, implementation and supervision of projects and procedures focused on improving the environmental performance of the company as a whole.

The 5W2H and GUT Matrix (GUT) are tools which can contribute to determine the functions and responsibilities of the team to achieve the aims based on integration.

\subsubsection{Identification of barriers and limitations}

Barriers to implementation of CP procedures may be economic, environmental and technological. Often they are treated in isolated ways, reducing the vision and power of management for these problems. The integration of these obstacles to the EMS, taking into account other aspects and sectors of the company, can enable the systematic search for solutions to problems. Furthermore, the identification, selection and implementation of CP opportunities can increase the reliability of the process of decision making, in other words, with a holistic view promoted by the integration of management system with other business sectors, the enterprise can to prioritize its needs without have isolated and partial errors in the decision process. It is recommended at this stage the use of Quality Management tools and programs to assist the identification and management of environmental problems and solutions.

This very concept applies in the analysis of environmental sustainability, economic and technical. Such analyzes realized alone and by sectors tend to take into account individual and partial aspects for each sector. Applied in a systematic way, with the structure of EMS, these analyzes are structured and focused on business objectives in its entirety, thus minimizing isolated rigidity from each sector of the organization.

\subsection{Integration stage}

\subsubsection{Identification and control of environmental aspects and impacts}

Focusing on EMS and the CP and one of the main points of mutual compatibility, the identification and control of environmental aspects and impacts represent the main actions to improve the environmental performance of organizations. It should be carried out systematically and based on environmentally impactful processes that the company has.

Integrated management performed by EMS and by $\mathrm{CP}$ aims at maximizing the efficiency of this process and to reduce the obstacles, focusing on the minimization, control and prevention of environmental problems arising from the activities of the company. It is recommended the use of Quality tools and Environmental Impact Assessment (EIA) processes mainly and also other activities of the company. Moreover, at this stage suggests the use of tools and programs of quality management, focusing their scopes in solving environmental problems.

The control of environmental aspects and impacts should be closely linked to monitoring and measurement, because this is one of the main objectives of the EMS and CP. In this moment, the integration team should be prepared to identify the root cause of the environmental impacts of the organization. The lshikawa diagram and Current Reality Tree (CRT) are important tools to this aim.

\subsubsection{Documentation and communication}

Documentation is auditor item for EMS. However, as there is no audit, the $\mathrm{CP}$ procedures not necessarily have specific documentation. However, as many cases of CP procedures may represent important environmental and economic benefits for companies, as well as having high levels of environmental risk and safety, becomes a necessary integration of this documentation, as practices environment are, in many cases, items managed by the EMS.

The preparation and work instructions to ensure operational control of the integration should be performed and documented, allowing the verification and analysis of record for each procedure.

In addition to this importance, the integration of records and documentation control under centralized management allows maximum efficiency of these processes of documentation control, reducing workloads and maximizing efficiency. 


\subsubsection{Operational control}

Integrated processes and instructions will have strong impact on environmental performance, on management and on the production system of the company. The processes should follow the objectives proposed by integrating EMS and CP according to the proposed planning. The indicators in turn must demonstrate the performance of the EMS and CP in an integrated way, allowing the management of resources and the proposed corrections if needed or in the case of monitoring objectives and goals are being met in accordance with planning.

It is emphasized that operational procedures may not be exactly the same for the EMS and the CP, since the first, being a management system, aims at managing processes while $\mathrm{CP}$, being a strategy of production techniques, aims at practical application of operational procedures. This reinforces the mutual benefit because management complements the technical operational control, under the approach of operations management.

The EMS has a facing requirement for contingency plans which should also be used in an integrated manner, as many $\mathrm{CP}$ projects require close supervision to prevent any environmental accidents and occupational health. With that emergency, plans must be contained in this integration. Again it is suggested the use of Quality tools and programs for control and management procedures in accordance with environmental objectives.

\subsection{Evaluation and analysis stage}

\subsubsection{Monitoring and measurement}

It should be carried out the monitoring and measurement of the EMS and CP by themselves, and subsequently to perform them integrally. This practice assesses the performance of the integration of EMS with the $\mathrm{CP}$ and evaluates whether the results are consistent with the goals and targets of the company and meet legal and environmental requirements.

Thus, one should propose sets indicators or indicators that allow joint analysis for the EMS and the $\mathrm{CP}$, allowing a company's environmental management as a whole. These analyzes will be able to check the organization's environmental performance and identify strengths and weaknesses for future improvements. Furthermore, these analyzes will be able to contribute on the evaluation of the performance of the integration between EMS and CP to environmental objectives of the company.

Of course, this study identified that the five surveyed companies do not have the means to distinguish and determine if the environmental benefits are the result of the EMS or CP. Thus it is observed and concluded that the integration of environmental indicators, their analysis and monitoring, also performed in an integrated manner to promote greater efficiency of management processes. For this, guideline integration becomes important to use tools for management, production management and quality management, focusing on environmental improvements of processes.

\subsubsection{Internal audit}

No need formal audit for CP, which is only required to comply with a requirement of ISO 14001. However, with the integration of objectives, goals and other items between the EMS and the CP, it becomes an effective measure that integrated activities are monitored and audited, thus enabling management control of all environmental activities.

In addition, internal audit prevents failures, identifies opportunities for improvement and enhances the integration between the EMS and CP, allowing larger numbers of information for management analysis. These internal audits can be performed by internal trained staff, if it contains members of the team responsible for the EMS or the CP and its integration by third parties that although represent additional costs for the contracting organization allows for greater reliability in their audit results.

\subsubsection{Critical analysis of the direction}

The management should periodically review the organization's environmental performance through the evaluation of the results of the integration of EMS and CP. These meeting analyzes should be based on indicators and results of internal audits. Furthermore, they must be conducted in a structured way so they are not overlooked important points of analysis.

The analysis of the direction has as main objectives to verify the performance of the company in relation to its policy, objectives and targets and thereby identifying the need for improvements and revisions in strategic, tactical and operational planning.

\subsubsection{Corrective, preventive and continuous improvement}

Noting up errors and faults, also known as non-conformities management systems should be proposed mitigating actions for the environmental objectives of the company have the possibility of being achieved. In addition, as the $\mathrm{CP}$ has preventive 
focus, it is necessary to propose preventive measures for environmental impacts of the company.

Verifying, correcting the nonconformities and prevent their recurrence and preventing the incidence of major non-conformity through prevention can contribute to the process of continuous environmental improvement company.

Both the EMS and CP are based on the principles of continuous improvement through PDCA (Plan, Do, Check and Act). Environmental practices based now so integrated prevention and control of environmental impacts of business activities should be proposed according to the continuous improvement cycle.

\section{Conclusion}

The main contribution of this work is on proposing guidelines for the integration of the EMS based on ISO 14001 and CP. Current research has studied the issue form a broad perspective, and has not presented practical recommendation for integration. The integration between these two elements deserves attention because it may represent an important mean to reduce costs, reduce bureaucracy, increase efficiency and environmental efficiency and the improvement in operational control of production processes and environmental companies.

Besides the integration of CP and EMS and the identification of their compatibility, the benefits and difficulties between the EMS based on ISO 14001 and $\mathrm{CP}$ presented in this study can serve as a benchmarking for companies interested in environmental issues and practices in general.

As a research limitation, it is worth underscoring that case studies do not permit generalizations. Their findings refer exclusively to those concepts discussed in the review of the researched companies. This research method permits describing complex situations and comparing them with conceptual elements raised in the theoretical review, thus revealing new aspects about the themes handled. A generally neglected aspect in the studies regarding these two themes, but observed in this study, refers to the organizational culture and its influence on implementing effective environmental practices by different stakeholders, such as collaborators, clients and suppliers.

Another limitation refers to the fact that the guidelines have not been tested in practice after their formulations. These guidelines are an initial step to the futures studies more profound in the way of integration proposed. It is recommended that each step of the implementation and integration between the EMS and the CP be taken more explored in the practice in enterprises, since these guidelines were developed after the exploratory research.

It was not possible to conclude that the EMS and $\mathrm{CP}$ are compatible in its entirety, however the study can contribute towards industries and companies that try to implement or even maintain EMS and CP procedures jointly and simultaneously, or even in isolation, since the results of this study show the main compatibilities between these two environmental management elements. These converging points can serve as guidance for organizations to direct their human, technological and financial resources in a direct and objective manner.

The study can contribute towards the environment because it gathers an adequate theoretical reference about EMS based on ISO 14001 and CP. Furthermore, the study presents important practices at five large Brazilian industries regarding these two environmental management themes. As a suggestion for future studies as continuations of this research, the sample size should be increased, applying the study to more companies, and quantitative methods of research should be used, thus providing a broader scenario of information in the business sector.

\section{References}

Barbiroli, G., \& Raggi, A. (2003). A method for evaluating the overall technical and economic performance of environmental innovations in production cycles. Journal of Cleaner Production, 11(4), 365-374. http://dx.doi. org/10.1016/S0959-6526(02)00058-6

Biolchini, J., Mian, P. G., Natali, A. C. C., \& Travassos, G. H. (2005). Systematic review in software engineering. Rio de Janeiro: UFRJ. PMid:16210999.

Biolchini, J. C. A., Mian, P. G., Natali, A. C. C., Conte, T. U., \& Travassos, G. H. (2007). Scientific research ontology to support systematic review in software engineering. Advanced Engineering Informatics, 21(2), 133-151. http://dx.doi.org/10.1016/j.aei.2006.11.006

Burke, S., \& Gaughran, W. F. (2006). Intelligent environmental management for SMEs in manufacturing. Robotics and Computer-Integrated Manufacturing, 22(5-6), 566-575. http://dx.doi.org/10.1016/j.rcim.2005.11.008

Burritt, R. L., Herzig, C., \& Tadeo, B. D. (2009). Environmental management accounting for cleaner production: the case of a Philippine rice mill. Journal of Cleaner Production, 17(4), 431-439. http://dx.doi.org/10.1016/j. jclepro.2008.07.005

Cagno, E., Trucco, P., \& Tardini, L. (2005). Cleaner production and profitability: analysis of 134 industrial pollution prevention (P2) project reports. Journal of Cleaner Production, 13(6), 593-605. http://dx.doi.org/10.1016/j. jclepro.2003.12.025

Campos, L. M. S. (2012). Environmental management systems (EMS) for small companies: a study in Southern Brazil. Journal of Cleaner Production, 32, 141-148. http:// dx.doi.org/10.1016/j.jclepro.2012.03.029 
Cauchick-Miguel, P. A. (2007). Estudo de caso na engenharia de produção: estrutura e recomendações para a sua condução. Produção, 17(1), 216-229. http://dx.doi. org/10.1590/S0103-65132007000100015

Cerávolo, C. R., \& Müller, G. F. (2006). Organizational structure for cleaner production diffusion: a contribution of the six sigma method. Gestão \& Produção, 13(3), 531543.

Darbra, R. M., Ronza, A., Casal, J., Stojanovic, T. A., \& Wooldridge, C. (2004). The self diagnosis method: a new methodology to assess environmental management in sea ports. Marine Pollution Bulletin, 48(5-6), 420428. PMid:14980457. http://dx.doi.org/10.1016/j. marpolbul.2003.10.023

Eisenhartd, K. M. (1998). Building theories from case study research. Academy of Management Review, 14(4), 532550.

Fresner, J. (1998). Cleaner production as a means for effective environmental management. Journal of Cleaner Production, 6(3-4), 171-179. http://dx.doi.org/10.1016/ S0959-6526(98)00002-X

Frondel, M., Horbach, J., \& Rennings, K. (2007). Endof-pipe or cleaner production? An empirical comparison of environmental innovation decisions across OECD countries. Business Strategy and the Environment, 16(8), 571-584. http://dx.doi.org/10.1002/ bse.496

Fryxell, G. E., \& Szeto, A. (2002). The influence of motivations for seeking ISO 14001 certification: an empirical study of ISO 14001 certified facilities in Hong Kong. Journal of Environmental Management, 65(3), 223238. PMid:12357656. http://dx.doi.org/10.1006/ jema.2001.0538

Gale, R. (2005). Environmental costs at a Canadian paper mill: a case study of Environmental Management Accounting (EMA). Journal of Cleaner Production, 14(14), 12371251. http://dx.doi.org/10.1016/j.jclepro.2005.08.010

Ganeshkumar, B., Gobinath, R.; Mahendran, N. (2009). Based ecomapping of industries a potential tool for environmental performance analysis and optimization. In International Conference on Computer Engineering and Technology (ICCET), Singapore.

Giannetti, B. F., Almeida, C. M. V. B., Bonilla, S. H., \& Ribeiro, C. M. (2008). Life cycle inventory of dental syringes. Produção, 18(1), 155-169.

Instituto Brasileiro de Geografia e Estatística - IBGE. (2010). Retrieved from http://www.ibge.gov.br

Instituto Nacional de Metrologia, Qualidade e Tecnologia - INMETRO. (2011). ISO 14001 certified companies. Rio de Janeiro. Retrieved from www.inmetro. gov.br

International Organization for Standardization. (2004). ISO 14001:2004: Environmental management systems: requirements with guidance for use. Geneva.

Jaju, S. B., \& Mohanty, R. P. (2008). Economics of environment management system: a quality cost perspective. In First International Conference on Emerging Trends in Engineering and Technology (ICETET), Nagpur, Maharashtra.

Jasch, C. (2003). The use of Environmental Management Accounting (EMA) for identifying environmental costs. Journal of Cleaner Production, 11(6), 667-676. http:// dx.doi.org/10.1016/S0959-6526(02)00107-5
Jupp, V. (2006). The Sage dictionary of social research methods. London: Sage Publications.

Khalili, N. R., \& Duecker, S. (2013). Application of multicriteria decision analysis in design of sustainable environmental management system framework. Journal of Cleaner Production, 47, 188-198. http://dx.doi. org/10.1016/j.jclepro.2012.10.044

Khan, F. l., Sadiq, R., \& Husain, T. (2002). GreenPro-l: a risk-based life cycle assessment and decision-making methodology for process plant design. Environmental Modelling \& Software, 17(8), 669-692. http://dx.doi. org/10.1016/S1364-8152(02)00028-2

Khan, Z. (2006). Cleaner production: an economical option for ISO certification in developing countries. Journal of Cleaner Production, 16(1), 22-27. http://dx.doi. org/10.1016/j.jclepro.2006.06.007

Kleměs, J. J., Varbanov, P. S., \& Huising, D. (2012). Recent cleaner production advances in process monitoring and optimisation. Journal of Cleaner Production, 34, p. 1-8. http://dx.doi.org/10.1016/j.jclepro.2012.04.026

Lee, Y. E., \& Koh, K. K. (2002). Decision-making of nuclear energy policy: application of environmental management tool to nuclear fuel cycle. Energy Policy, 30(13), 1151-1161. http://dx.doi.org/10.1016/ S0301-4215(02)00004-6

Lundberg, K., Balfors, B., \& Folkeson, L. (2009). Framework for environmental performance measurement in a Swedish public sector organization. Journal of Cleaner Production, 17(11), 1017-1024. http://dx.doi. org/10.1016/j.jclepro.2009.01.011

Matthews, D. H., Christini, G. C., \& Hendrickson, C. T. (2004). Five elements for organizational decision-making with an environmental management system. Environmental Science \& Technology, 38(7), 1927- 1932. http://dx.doi. org/10.1021/es0351239

Nagel, M. H. (2003). Managing the environmental performance of production facilities in the electronics industry: more than application of the concept of cleaner production. Journal of Cleaner Production, 11(1), 11-26. http://dx.doi.org/10.1016/S0959-6526(02)00021-5

Rao, P., \& Holt, D. (2005). Do green supply chains lead to competitiveness and economic performance? International Journal of Operations \& Production Management, 25(9), 898-916. http://dx.doi. org/10.1108/01443570510613956

Riaz, A., Zahedi, G., \& Kleměs, J. J. (2013). A review of cleaner production methods for the manufacture of methanol. Journal of Cleaner Production, 57(15), 19-37. http://dx.doi.org/10.1016/j.jclepro.2013.06.017

Scavone, G. M. (2006). Challenges in internal environmental management reporting in Argentina. Journal of Cleaner Production, 14(14), 1276-1285. http://dx.doi. org/10.1016/j.jclepro.2005.08.011

Shah, S. K., \& Corley, K. G. (2006). Building better theory by bridging the quantitative- qualitative divide. Journal of Management Studies, 43(8), 1821-1835. http://dx.doi. org/10.1111/j.1467-6486.2006.00662.x

Shi, H., Chertow, M., \& Song, Y. (2010). Developing country experience with eco-industrial parks: a case study of the Tianjin Economic-Technological Development Area in China. Journal of Cleaner Production, 18(3), 191-199. http://dx.doi.org/10.1016/j.jclepro.2009.10.002 
Silva, G. C. S., \& Medeiros, D. D. (2004). Environmental management in Brazilian companies. Management of Environmental Quality: An International Journal, 15(4), 380-388. http://dx.doi. org/10.1108/14777830410540126

Silva, D. A L., Delai, 1., Castro, M. A. S., \& Ometto, A. R. (2013). Quality tools applied to Cleaner Production programs: a first approach toward a new methodology. Journal of Cleaner Production, 47, 174-187. http:// dx.doi.org/10.1016/j.jclepro.2012.10.026

Staniskis, J. K., \& Stasiskiene, Z. (2006). Environmental management accounting in Lithuania: exploratory study of current practices, opportunities and strategies intents. Journal of Cleaner Production, 14(14), 1252-1261. http://dx.doi.org/10.1016/j.jclepro.2005.08.009

Stechemesser, K., \& Guenther, E. (2012). Carbon accounting: a systematic literature review. Journal of Cleaner Production, v. 36, p. 17-38. http://dx.doi.org/10.1016/j. jclepro.2012.02.021

Suh, S. (2004). Functions, commodities and environmental impacts in an ecological-economic model. Ecological Economics, 48(4), 451-467. http://dx.doi.org/10.1016/j. ecolecon.2003.10.013

Tam, V. W. Y., Tam, C. M., Zeng, S. X., \& Chan, K. K. (2006a). Environmental performance measurement indicators in construction. Building and Environment, 41(2), 164173. http://dx.doi.org/10.1016/j.buildenv.2005.01.009

Tam, V. W. Y., Tam, C. M., Shen, L. Y., Zeng, S. X., \& Ho, C. M. (2006b). Environmental performance assessment: perceptions of project managers on the relationship between operational and environmental performance indicators. Construction Management and Economics, 24(3), 287-299. http://dx.doi. org/10.1080/01446190500372197

Thoumy, M., \& Vachon, S. (2012). Environmental projects and financial performance: Exploring the impact of project characteristics. International Journal of Production Economics, 140(1), 28-34. http://dx.doi.org/10.1016/j. ijpe.2012.01.014

Tove, M., \& Mauritz, G. (2006). Selecting problem-related environmental indicators for housing management. Building Research \& Information, 34(4), 321-333. http://dx.doi.org/10.1080/09613210600733658

Tranfield, D., Denyer, D., \& Smart P. (2003). Towards a methodology for developing evidence-informed management knowledge by means of systematic review.
British Journal of Management, 14, 207-222. http:// dx.doi.org/10.1111/1467-8551.00375

United Nations Environment Programme - UNEP. (2002). Industry and Environment. Prague.

United Nations Industrial Development Organization - UNIDO. United Nations Environment Programme - UNEP. (2011). How to stablish and operate claner production centers: guidance manual. Vienna.

Van Hoof, B., \& Lyon, T. P. (2013). Cleaner production in small firms taking part in Mexico's Sustainable Supplier Program. Journal of Cleaner Production, 41, 270-282. http://dx.doi.org/10.1016/j.jclepro.2012.09.023

Voss, C., Tsikriktsis, N., \& Frohlich, M. (2002). Case research in operations management. International Journal of Operations and Production Management, 22(2), 195219. http://dx.doi.org/10.1108/01443570210414329

Yin, R. K. (2003). Case study research: design and methods (3 rd ed.). California: Sage Publications.

Yusup, M. Z., Mahmood, W. H. W., Salleh, M. R., \& Muhamad, M. R. (2014). The influence factor for the successful implementation of cleaner production: a review. Jurnal Teknologi, 67(1), 89-97. http://dx.doi.org/10.11113/ jt.v67.2160

Zeng, S. X., Tam, C. M., Tam, V. W. Y., \& Deng, Z. M. (2005). Towards implementation of ISO 14001 environmental management systems in selected industries in China. Journal of Cleaner Production, 13(7), 645-656. http:// dx.doi.org/10.1016/j.jclepro.2003.12.009

\section{Acknowledgements}

The authors thank the Foundation for Research Support of the State of São Paulo (FAPESP), the Coordination of Improvement of Higher Education Personnel (CAPES) and the National Council for Scientific and Technological Development (CNPq) for financial support for the realization of research. 